\title{
INVESTIGATION OF STATIC LATERALLY LOADED PILE IN LAYERED SANDY SOIL
}

\author{
S M H Uddin ${ }^{1}$ and M N Islam²
}

\begin{abstract}
Investigation of the static lateral load resistance of pile on layered sandy soil was made by laboratory model test on single pile. The experiment was carried out with variable diameter and variable embedded length of pile on sandy soil. In this study, model pile was single pile which satisfies the Meyerhof's Relative Stiffness limit of pile for flexible pile. Single pile embedded length, $\mathrm{L}=0.46 \mathrm{~m}, 0.609 \mathrm{~m}, 0.762 \mathrm{~m}$ for pile diameter, $\mathrm{d}=0.013 \mathrm{~m}, 0.019 \mathrm{~m}, 0.026 \mathrm{~m}$, respectively. And for surcharge condition embedded length of single pile, $\mathrm{L}=0.609 \mathrm{~m}$ and surcharge of pressure, $\mathrm{P}=3369.55 \mathrm{Kg} / \mathrm{m}^{3}, \mathrm{P}=6739.1 \mathrm{Kg} / \mathrm{m}^{3}$ and $\mathrm{P}=13478.20 \mathrm{Kg} / \mathrm{m}^{3}$ for each diameter and for saturated condition of pile diameter, $\mathrm{d}=0.013 \mathrm{~m}$. These experiments were conducted with local sand of Rajshahi region and domar sand; available in Bangladesh. Lateral static loads were applied in the single by a static lateral load set up arrangement. Due to the static lateral load the pile was deflected. The load-displacement response, ultimate resistance of pile has been qualitatively and quantitatively investigated in the experiment. The lateral resistance of pile obtains by experiment and the ultimate lateral load resistances obtained by analytical methods were compared. The load displacement curves are similar and non-linear. Lateral failure at a pile head displacement from 8 to 10,7 to 9 and 6 to $8 \mathrm{~mm}$ for single pile of $\mathrm{d}=$ $0.013 \mathrm{~m}, 0.019 \mathrm{~m}$ and $0.026 \mathrm{~m}$, respectively. In the case of saturated condition of sand a pile head displacement $15 \mathrm{~mm}$ for single of $\mathrm{d}=0.013 \mathrm{~m}$. It observed that the failure load was the point at which the curve exhibits a pick or maintains continuous displacement increase with no further increase in lateral resistance.
\end{abstract}

Keywords: Pile, Lateral pile, simplified analytical method, ultimate lateral load resistance

\section{INTRODUCTION}

Piles are vertical or slightly inclined relatively slender structural members which have the function of transferring load from the superstructure through weak compressible, strata or through water, onto stiffer or more compact and less compressible soil or onto rock. Piles may be required to carry uplift loads when used to support tall structures subjected to overturning forces from winds or waves and earthquake force. Some times piles are subjected to lateral load, for example piles used in marine structure, such as in quay and harbor structure. The sources of lateral load on harbor (marine) structure type of pile foundation, two criteria should be consider as safe against ultimate load failure and deflection should be with in permissible limits in working load. For design such types of piles, ultimate lateral resistance of pile are required on the basis of above criteria.

When plies are situate in a soft soil layer that is subjected to horizontal moment, horizontal pressure are develop between the pile and soil with a consequent development of bending moments and deflections in the piles is called lateral pile. When plies are situate in a soft soil layer that are impact of berthing ships wave action and off-shore structure are also subjected to wind and wave. High rise building, tower are subjected to lateral load due to wind and earthquake force. Combination of vertical and horizontal loads is carried where piles are used to support retaining walls, bridge piers and abutment and machinery foundations. So, it is important to know the lateral load to resistance capacity of pile foundation. When determining the resistance capacity of such tips subjected to horizontal moment, horizontal pressures are developed. The square crosssection piles is one of the most common type of deep foundation to support high rise building especially in southeast Asia (Fellenius et al. 1999 and Zhang, 2003).

The various forces act on the laterally loaded pile such as wind forces, water forces, ship impact, surge, swing and sway of ship, ship mooring, ice thrust, force acting railway on bridge, ice thrust, force acting

1 Institute of Environmental Science, University of Rajshahi, Rajshahi-6205, Bangladesh.

2 Department of Civil Engineering, Rajshahi University of Engineering \& Technology, Rajshahi-6204, Bangladesh 
railway on bridge, soil flow, earthquake force etc. Vertical pile resists horizontal loads or moments by deflecting until the necessary reaction in the surrounding soil is mobilized. This lateral load resistance of pile foundations is critically important in the design of structures under loading from earthquakes, soil movement, waves etc. According to Poulos and Davis (1980) the maximum deflection of the pile is the major criterion on the design. The piles transfer the load of the superstructure through two ways: (a) Shear generated along the surface of the pile due to soil-pile friction; (b) Point resistance due to the bearing of the pile at its bottom. The behaviour of the foundation under such loading conditions depends essentially on the relative stiffness of the pile and the soil.

Three main factors are very important to be considered in most of the projects including soil stress, bearing capacity of pile and lateral displacement of pile, respectively (Avaei et al. 2008). Despite the recent progress in soil mechanics, determination of piles behaviour especially under lateral loads and in the layered soils is difficult. Properties of soil, the length of the piles, the diameter, the section shape and the employed empirical method are led to complexity of the interaction between pile and the surrounding soil.

\section{MATERIALS AND METHODS}

\section{Methods of Analysis}

In this research, considering the variously presented methods, three of them are very useful and applicable are employed in order to analyze the vertical piles under the lateral loads. Three methods are investigated in the layered soils which include Matlock and Reese (1960), Meyerhof's (1995) and Patra and Pise's (2001) method, respectively.

\section{Experimental setup and testing program Foundation}

Layered sand (coarse sand is overlying the finer sand) was the foundation medium and the model tank size was $1 \mathrm{mx} 1 \mathrm{mx} 1 \mathrm{~m}$. Layered soil contains the layered sand whose have different density, specific gravity etc. Sand has a placement density for sample $(1), \gamma_{1}=15.57 \mathrm{KN} / \mathrm{m}^{3}$ and angle of internal friction, $\varphi_{1}=58.28^{\circ}$. Sample (2) has a placement density, $\gamma_{2}=15.2 \mathrm{KN} / \mathrm{m}^{3}$ and angle of internal friction, $\varphi_{2}=67.09^{\circ}$.

\section{Pile cap and model pile}

Pile cap are almost invariable made of reinforced concrete $\&$ are designed as individual footings subjected to the column loads plus the weight of the pile cap $\&$ the soil above the cap. In this experiment G.I weir was used as pile cap. Single pile of $1 \mathrm{~m}$ length and its embedded length, $\mathrm{L}=0.460 \mathrm{~m}, 0.609 \mathrm{~m}$ and $0.762 \mathrm{~m}$ for each pile of diameter, $\mathrm{d}=0.013 \mathrm{~m}, 0.019 \mathrm{~m}$ and $0.026 \mathrm{~m}$ were tested.

\section{Experimental setup}

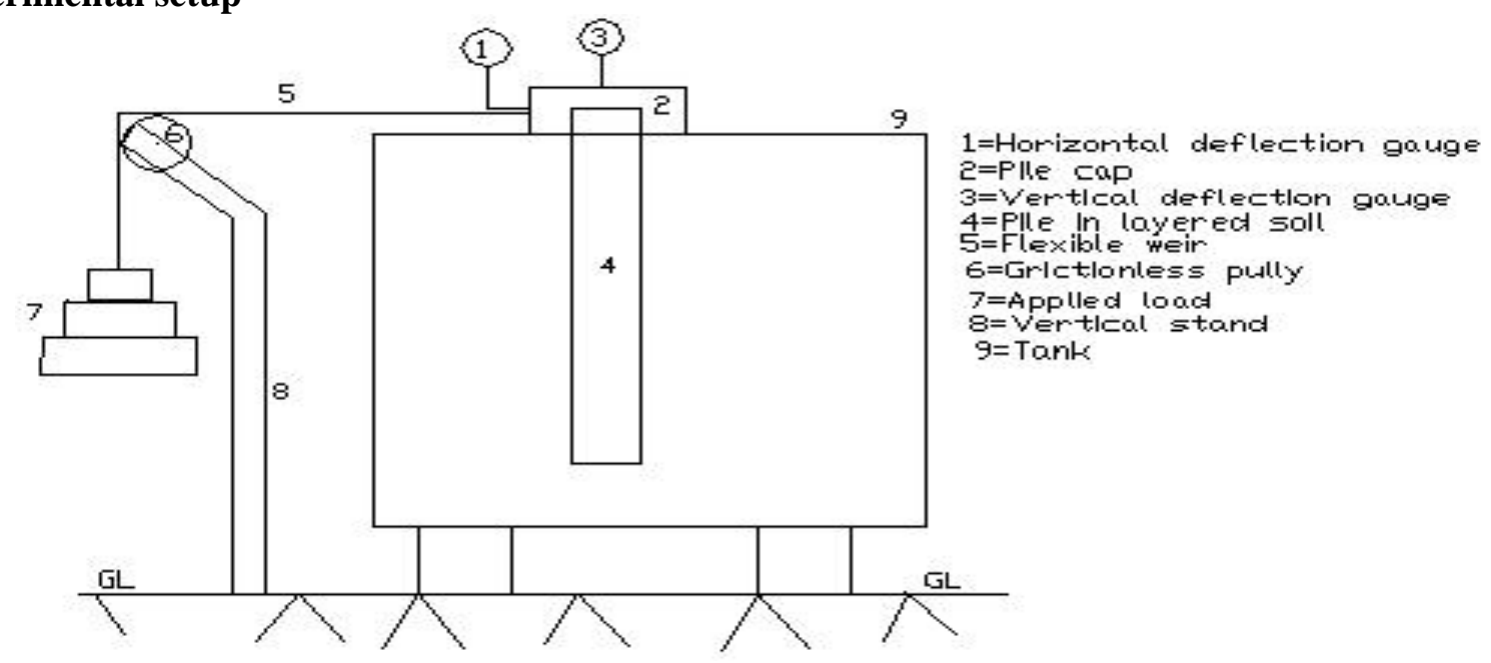

Layout of working arrangement

In this experiment, piles were subjected to lateral load and for this purpose an experimental setup were made same as the above layout. At first, the model pile or piles were placed in the model tank of dimension $(1 \mathrm{mx} 1 \mathrm{mx} 1 \mathrm{~m})$, then the local sand placed at $0.50 \mathrm{~m}$ depth from bottom of the tank and domar sand placed over the local sand at $0.50 \mathrm{~m}$ depth and both were placed in his tank from a certain height $(0.50 \mathrm{~m})$ for maintaining fairly uniformly placement density. For applying lateral pull in the pile, a flexible weir was attached in the pile cap and vertical stand with frictionless pulley was used to change the direction of vertical 
load to lateral load. One dial gauges were attached to the pile cap to measure the lateral and vertical deflection of the pile.

\section{Experimental procedure}

The arrangement of test setup is shown in above working layout. Loading arrangement were made in such a way that it will act laterally to pile cap. After placing piles with the pile cap in the tank, layered soil was placed in the tank by falling from certain height of about $0.50 \mathrm{~m}$. The lateral load was applied to the pile cap through a pulley arrangement with flexible weir attached to the pile cap. The other end was attached to the loading to the loading apron. Load was applied by dead weight over the loading pan starting form the smallest with gradual increase in stages. Same loading were maintained for all model pile. The loading sequences were $1,2,3,4,5,6,7,8,9,10,11,12,13,14,15,16,17,18,19$ 2,21,22 ,23, 24, 25, 26, 27, 28, 29, $30,31,32,33,34,35,36,37,38,39,40 \mathrm{Kg}$ etc. Dial gauge having sensitivity $0.01 \mathrm{~mm}$ was used for measuring the lateral vertical direction. When load was placed in the loading pan, it moves down and due to the pulley it act laterally to the pile cap. Due to the lateral load, the piles were deflecting in the direction of the lateral load and the dial gauge gave the reading of the deflection of the pile. Due to lateral load the pile (s) were deflecting in the direction of lateral load and Dial gauge gave the reading of the deflection of the pile. Deflections for corresponding load were noted.

\section{RESULTS AND DISCUSSIONS}

The ultimate lateral resistance of the pile found out by plotting lateral load Vs displacement diagram in the plain graph paper. At the ultimate resistance, pile showed some deflection without any increase in load and this load was taken as ultimate load for the pile. The load displacement curves are in general, similar and non-linear. Pull versus deflections in embedded length, $\mathrm{L}=0.460 \mathrm{~m}, 0.609 \mathrm{~m}$, and $0.762 \mathrm{~m}$ single piles of diameter, $\mathrm{d}=0.013 \mathrm{~m}, 0.019 \mathrm{~m}$ and $0.026 \mathrm{~m}$ for same loading sequence in dry condition were shown in Fig 1 . Pull versus deflections due to surcharge/overburden pressure, $\mathrm{P}=3369.55 \mathrm{Kg} / \mathrm{m}^{3}, \mathrm{P}=6739.1 \mathrm{Kg} / \mathrm{m}^{3}$ and $\mathrm{P}=13478.20 \mathrm{Kg} / \mathrm{m}^{3}$; embeded length, $\mathrm{L}=0.762 \mathrm{~m}$, single piles of diameter, $\mathrm{d}=0.013 \mathrm{~m}, 0.019 \mathrm{~m}$ and $0.026 \mathrm{~m}$ for same loading sequence in dry condition were shown in Fig 2. Pull versus deflections of piles of embeded length, $\mathrm{L}=0.609 \mathrm{~m}$ and diameter of pile, $\mathrm{d}=0.013 \mathrm{~m}$ when the sample was fully saturated for same loading sequence in Fig. 3. From the lateral pull versus lateral displacement diagrams, for a particular value of lateral movement of pile, the magnitude of pull increases with increase embedded length. Lateral failure at a pile head displacement from 8 to $10 \mathrm{~mm}$ for single pile of pile diameter, $\mathrm{d}=0.013 \mathrm{~m}$. However, for $\mathrm{d}=0.019 \mathrm{~m}$, the lateral failure occurred at a pile head displacement of 7 to $9 \mathrm{~mm}$ of single pile. Also lateral failure at a pile head displacement from 6 to $8 \mathrm{~mm}$ for single of $\mathrm{d}=0.026 \mathrm{~m}$. In the case of saturated condition of sand a pile head displacement $15 \mathrm{~mm}$ for single of $\mathrm{d}=0.013 \mathrm{~m}$. It is observed that the failure load is the point at which the curve exhibits a pick or maintains continuous displacement increase with no further increase in lateral resistance. The observed load were $156 \mathrm{~N}, 205 \mathrm{~N}$ and $284.49 \mathrm{~N}$ for $\mathrm{L}=0.46 \mathrm{~m}, 0.609 \mathrm{~m}$ and $0.762 \mathrm{~m}$ of pile $\mathrm{d}=$ $0.013 \mathrm{~m}$ where the calculated load found from Meyerof theory $(205.59 \mathrm{~N}, 227.36 \mathrm{~N} \& 292.67 \mathrm{~N})$, Patra \& Pise method $(190.89 \mathrm{~N}, 204.31 \mathrm{~N} \& 349.90 \mathrm{~N})$ and Elastic theory load $(118.60 \mathrm{~N}, 104.63 \mathrm{~N} \& 91.07 \mathrm{~N})$, respectively (Table.1). The observed load were $137.34 \mathrm{~N}, 186.39 \mathrm{~N} \& 304.11 \mathrm{~N}$ for $\mathrm{L}=0.46 \mathrm{~m}, 0.609 \mathrm{~m}$ and $0.762 \mathrm{~m}$ of pile $\mathrm{d}=0.019 \mathrm{~m}$ where the calculated load found from Meyerof theory $(300.48 \mathrm{~N}, 332.3 . \mathrm{N} \&$ $277.5 \mathrm{~N})$, Patra \& Pise method (278.99N, 337.10N \& 277.5N) and Elastic theory load (212.34N, 184.82N \& $161.05 \mathrm{~N}$ ), respectively (Table.2). The observed load were $156.96 \mathrm{~N}, 304.11 \mathrm{~N} \& 176.58 \mathrm{~N}$ for $\mathrm{L}=0.46 \mathrm{~m}$, $0.609 \mathrm{~m}$ and $0.762 \mathrm{~m}$ of pile $\mathrm{d}=0.026 \mathrm{~m}$ where the calculated load found from Meyerof theory $(411.17 \mathrm{~N}$, $454.70 \mathrm{~N} \& 585.31 \mathrm{~N})$, Patra \& Pise method $(381.77 \mathrm{~N}, 461.28 \mathrm{~N} \& 699.80 \mathrm{~N})$ and Elastic theory load $(291.05 \mathrm{~N}, 253.28 \mathrm{~N} \& 216.93 \mathrm{~N})$, respectively (Table. 3). It was noted that ultimate lateral load resistance of pile in elastic theory depends on the allowable displacement of the pile. In saturated condition of soil, the observed load was $180 \mathrm{~N}$ whereas the calculated load from the Meyerof theory and Patra \& Pise method load were $142.21 \mathrm{~N}$ and $144.04 \mathrm{~N}$, respectively (Table. 4 ). 

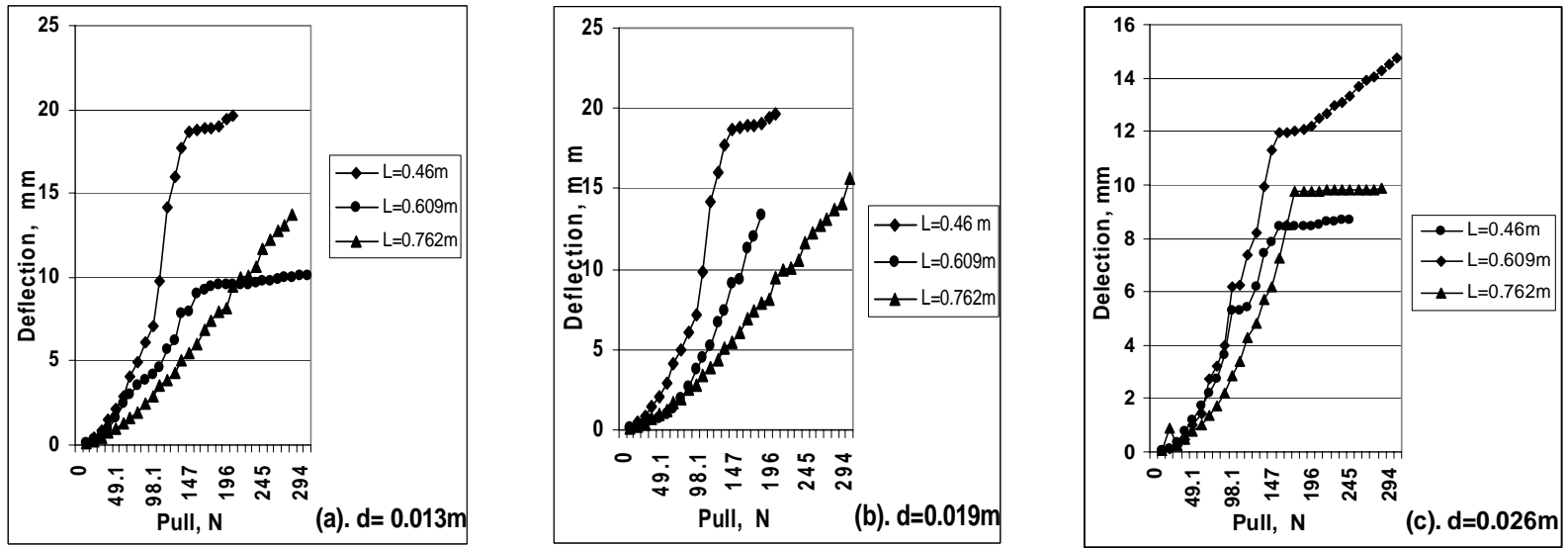

Fig.1: Pull Vs deflection diagram of different embedded length of pile of different diameter a). $\mathrm{d}=0.013 \mathrm{~m}$, (b). $d=0.019 \mathrm{~m}$ and (c). $d=0.026 \mathrm{~m}$.
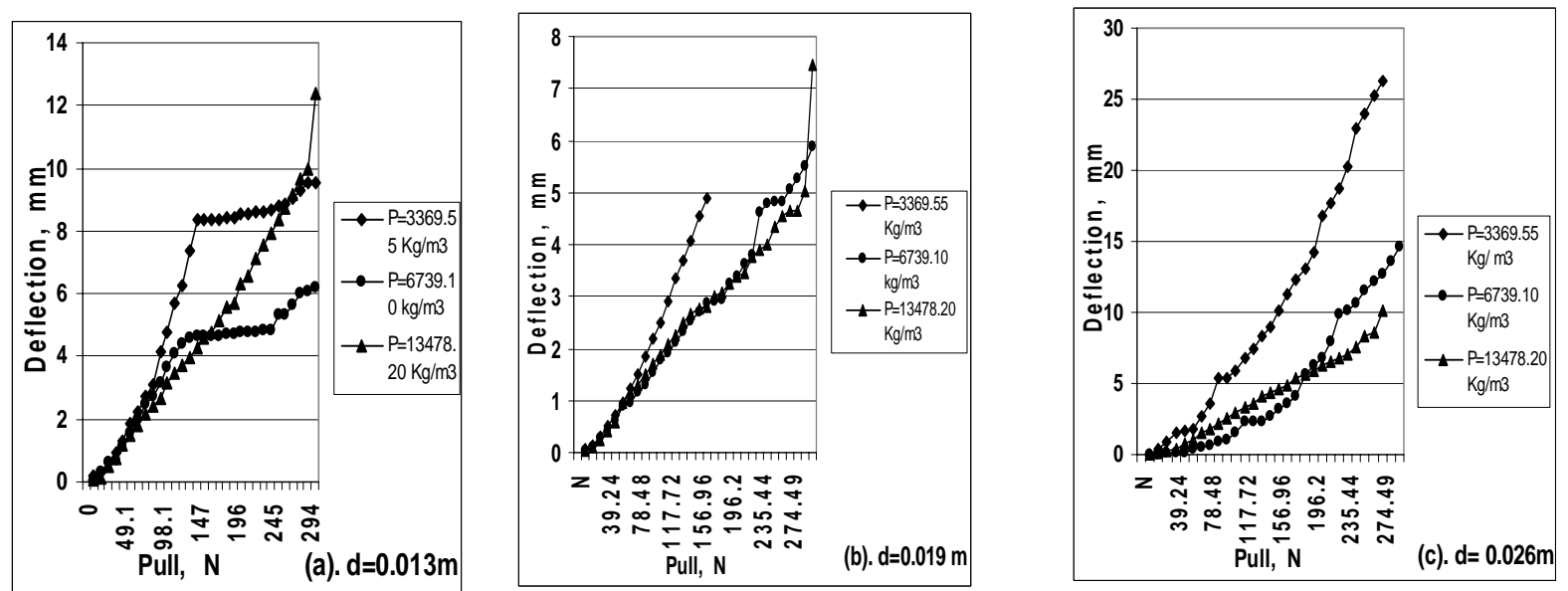

Fig.2 Pull Vs deflection diagram of embedded length, $\mathrm{L}=0.609 \mathrm{~m}$ of different diameter a). $\mathrm{d}=0.013 \mathrm{~m},(\mathrm{~b}) . \mathrm{d}=0.019 \mathrm{~m}$.and $(\mathrm{c}) . \mathrm{d}=0.026 \mathrm{~m}$ under surcharge condition.

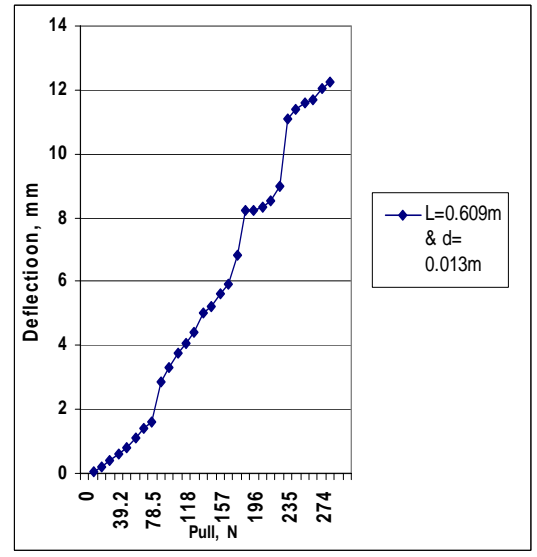

Fig. 3: Pull Vs deflection diagram of different embedded length, $L=0.609 \mathrm{~m}$ of diameter, $\mathrm{d}=0.013 \mathrm{~m}$ in saturated condition. 


\section{CONCLUSION}

The ultimate lateral capacity of pile and pile group depends on the varying embedded length, size of pile and sand placement density. The quantitative and qualitative influence of those parameters has been investigated. The load-displacement curves are non-linear. Lateral failure occurred at a pile head displacement from 8 to $10 \mathrm{~mm}$ for $\mathrm{d}=0.013 \mathrm{~m}$ with the variation of embedded length for single pile. However, for $\mathrm{d}=0.019 \mathrm{~m}$ the lateral failure occurred at a pile head displacement from 7 to $9 \mathrm{~mm}$ with the variation of embedded length for single pile. Also lateral failure occurred at a pile head displacement from 6 to $8 \mathrm{~mm}$ for $\mathrm{d}=0.026 \mathrm{~m}$ with the variation of embedded length for single pile. Ultimate resistance of $\mathrm{d}=0.013 \mathrm{~m}$ of single pile increase in dry condition is greater than single pile of $\mathrm{d}=0.013 \mathrm{~m}$ in saturated condition.

\section{ACKNOWLEDGMENTS}

The authors would like to acknowledge Dr. Md. Redwanur Rahman, Assistant professor, Institute of Environmental Science, University of Rajshahi for his suggestions and encouragement. The facilities provided by Department of Civil Engineering Soil Mechanics Lab, Rajshahi University of Engineering \& Technology (RUET) hereby, acknowledged.

\section{REFERENCES}

Avaei A, Ghotbi AR and Aryafar M. 2008. Investigation of Pile- Soil Interaction Subjected to Lateral Loads in Layered Soils. American J. of Engineering and Applied Sciences 1 (1): 76-81.

Fellenius BH, Altaee A, Kulesza R, and Hayes J. 1999. O-cell testing and FE analysis of 28-m-deep barrette in Manila, Philippines. J. of Geotechnical and Geoenvironmental Engineering. 125(7):566-575.

Matlock and Reese. 1961. Generalized Solution for laterally loaded piles. J. of the Soil Mechanics \& Foundations Division, ASCE. 86(1): 63-91.

Meyerhof GG. 1995. Behavior of Pile Foundations under Special Loading Conditions. Canadian Geotechnical J. 32(2): 204-222.

Patra NR and Pise PJ. 2001. Ultimate Lateral Resistance of Pile Groups in Sand. J. of Geotechnical and Geoenvironmetal Engineering. 127(6): 481-487.

Poulos HG and Davis EH. 1980. Pile Foundation Analysis and Design. John Wiley \& Sons, Inc, United States.

Zhang LM. (2003. Behavior of Laterally Loaded Large-Section Barrettes. J. of Geotechnical and Geoenvironmental Engineering. 129(7): 639-648. 


\section{TABLES}

Table: 1 Comparison of resistance of single pile of $\mathrm{d}=\mathbf{0 . 0 1 3} \mathrm{m}$ and different embedded length by different methods to experimental methods

\begin{tabular}{|l|l|l|l|l|}
\hline $\mathrm{d}=0.013 \mathrm{~m}$ & Observed load, & Calculated load & \multicolumn{3}{|l|}{} \\
\cline { 3 - 5 } & $\mathrm{N}$ & Meyerhof method, $\mathrm{N}$ & Patra \& Pise method, $\mathrm{N}$ & Elastic theory, $\mathrm{N}$ \\
\hline $\mathrm{L}=0.46 \mathrm{~m}$ & 156 & 205.59 & 190.89 & 118.60 \\
\hline $\mathrm{L}=0.609 \mathrm{~m}$ & 205 & 227.36 & 204.31 & 104.63 \\
\hline $\mathrm{L}=0.762 \mathrm{~m}$ & 284.49 & 292.67 & 349.9 & 91.07 \\
\hline
\end{tabular}

Table: 2 Comparison of lateral load resistance of single pile of $\mathrm{d}=\mathbf{0 . 0 1 9 m}$ and different embedded length by different methods to experimental methods

\begin{tabular}{|l|l|l|l|l|}
\hline $\mathrm{d}=0.019 \mathrm{~m}$ & $\begin{array}{l}\text { Observed load, } \\
\mathrm{N}\end{array}$ & & Calculated load & \multicolumn{2}{|l|}{} \\
\cline { 3 - 5 } & & Meyerhof method, N & Patra \&Pise method, N & Elastic theory, N \\
\hline $\mathrm{L}=0.46 \mathrm{~m}$ & 137.34 & 300.48 & 278.99 & 212.34 \\
\hline $\mathrm{L}=0.609 \mathrm{~m}$ & 186.39 & 332.30 & 337.10 & 184.82 \\
\hline $\mathrm{L}=0.762 \mathrm{~m}$ & 304.11 & 27.75 & 11.40 & 161.05 \\
\hline
\end{tabular}

Table: 3 Comparison of lateral load resistance of single pile of $\mathrm{d}=\mathbf{0 . 0 2 6} \mathrm{m}$ and different embedded length by different methods to experimental methods

\begin{tabular}{|l|l|l|l|l|}
\hline $\mathrm{d}=0.026 \mathrm{~m}$ & $\begin{array}{l}\text { Observed } \\
\text { load, }, \mathrm{N}\end{array}$ & Calculated load & \multicolumn{3}{|l|}{} \\
\cline { 3 - 5 } & Meyerhof method, $\mathrm{N}$ & Patra \& Pise method, $\mathrm{N}$ & Elastic theory, $\mathrm{N}$ \\
\hline $\mathrm{L}=0.46 \mathrm{~m}$ & 156.96 & 411.17 & 381.77 & 291.05 \\
\hline $\mathrm{L}=0.609 \mathrm{~m}$ & 304.11 & 454.70 & 461.28 & 253.60 \\
\hline $\mathrm{L}=0.762 \mathrm{~m}$ & 176.58 & 585.31 & 699.80 & 216.93 \\
\hline
\end{tabular}

Table: 4 Comparison of lateral load resistance of single pile of embedded length, $L=0.152 \mathrm{~m}$ and

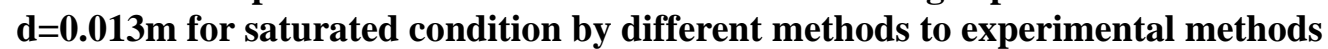

\begin{tabular}{|l|l|l|l|}
\hline \multirow{2}{*}{$\mathrm{L}=0.152 \mathrm{~m}$} & Observed load, $\mathrm{N}$ & Calculated load \\
\cline { 3 - 4 } & & Meyerhof method, N & Patra \& Pise method, N \\
\hline $\mathrm{D}=0.013 \mathrm{~m}$ & 180 & 142.21 & 144.04 \\
\hline
\end{tabular}

